\title{
IMPLEMENTING MULTIMEDIA-BASED INTEGRATED LEARNING OF CONCRETE CONSTRUCTION AND ENTREPRENEURSHIP TO IMPROVE THE STUDENTS' ENTREPRENEURIAL SPIRIT
}

\author{
V. Lilik Hariyanto ${ }^{1}$, Amat Jaedun ${ }^{2}$, Nuryadin Eko Rahardjo ${ }^{3}$, and F. Ma'arif ${ }^{4}$ \\ ${ }^{1,2,3}$ Faculty of Enginering, Universitas Negeri Yogyakarta, Indonesia \\ ${ }^{4}$ Faculty of Civil Engineering, Beihang University of Aeronautics and Astronautics, Beijing, China \\ E-mail: lilik_hariyanto@uny.ac.id
}

\begin{abstract}
The objectives of the study were: (1) to formulate a multimedia-based integrated learning model of concrete construction and entrepreneurship and, (2) to measure the improvement of the students' entrepreneurial spiritby implementing this developed integrated learning model in the classroom. This study was classified as a quasi-experimental study with a non-equivalent control group design. A pretest, treatment, andposttest were presented to the experimental and control groups. This study was conducted in 8 meetings at the Stone Installation and Concrete Constructionworkshop, Universitas Negeri Yogyakarta. Data were collected through tests to measure students' competence in entrepreneurship and Concrete Construction. The Concrete Construction skills were measured through product assessment. Testing of the validity and the reliability of the instruments used expert judgment and Cronbach Alpa respectively. Data were analyzed with a statistical t-test, with consideration of (a) the data normality, and (2) the homogeneity for the variance of each data group. This study concluded: (1) the integrated learning model was successfully formulated (2) there were positive and significant differences in the students' entrepreneurial spirit between the students treated with the developed integrated learning model and the students treated with the conventional learning model.
\end{abstract}

Keywords: entrepreneurship, entrepreneurial spirit, integrated learning model

\section{INTRODUCTION}

One of the influential factors in achieving learning outcomes isthe implementation of appropriate learning models in the learning process[1], [2]. A learning model is a conceptual framework and operational learning that hasnames, characteristics, logical order, settings, and culture[3]. Many studies suggested that the influence of learning models will be moreoptimal on the learning achievement if the model is adapted to the learning objectives by modifying or substituting relevant elements to the functional condition[4]-[7].

In the Department of Civil Engineering and Planning Education, Faculty of Engineering, Universitas Negeri Yogyakarta, the curriculum systematically integrates teacher training programs, vocational education, and industrial practice programs [8]. Integrated learning of productive lessons of civil engineering with entrepreneurship is in harmony with this curriculum. Through this integrated learning, ideally, students not only develop teaching skills as the main objectives of the institution, but the studentsare also expected to be independent entrepreneurs in the field of business aligned with their academic background. This can be achieved if the concept of learning between the two subjects can be integrated comprehensively.

Furthermore, learning outcomes can be achieved effectively and efficiently when the teaching-learning process is packaged in learning media that meets the students' characteristics [9]. Multimedia, in this case, is very potential to achieve integrated learning goals. Multimedia is a medium that combines two or more elements of media in an integrated way that is packaged in a new technique using a computer in a form of communication that includes text, sound, graphics, animation, photos, audio and video in a computer system.

The Indonesian government also supports the students to beindependent entrepreneurs after graduation. The government has issued a 
policy that regulates Entrepreneurship Skills Education Program [10]. The Ministry of Cooperatives, Small and Medium Enterprises has also issued a policy that the entrepreneurship learning program for students must continue to be improved. The Indonesian entrepreneurial ratio in2017 is still 3.1\%. It is $7 \%$ below Singapore, $5 \%$ below Malaysia and $4 \%$ below Thailand. It needs to be improved. The number of entrepreneurs in Indonesia still not reach the ideal number of $2 \%$ of the total population [11]. Data from the Global Entrepreneurship Monitor (GEM) shows that Indonesia only has around $1.65 \%$ of entrepreneurs from a total population of 250 million[12].

The subject of Concrete Construction in the Department of Civil Engineering and Planning Education, Faculty of Engineering, Universitas Negeri Yogyakarta is one of the main subjects to developmotoric skills in the field of Concrete Construction. In this case, the optimal achievement of the motoric skills qualifications of the students needs more effort because there were still several obstacles. One of them was that the teaching-learning process still used a conventional learning model that combined lectures and demonstrations by using job sheets. Also, each subject was still implemented separately, where these subjects could be collaborated to produce more comprehensive mastery. For example, the subject of Entrepreneurship should collaborate with productive learning that creates a product to sell in the market, [13], [14]. This partial learning model impacts negatively on theachievement of vocational education especially entrepreneurship oriented to promote graduates to start entrepreneurship independently. Thisoften brings students to behave apathetic and less motivated to learn entrepreneurial skills. This learning modelis not interesting and motivating for students because of the lack of learning media variation. At the same time, the development of learning media has been very fast in other vocational education institutions. Learning materials should be packaged in interesting multimedia learning presented with dynamic animations to encourage students' motivation.

Therefore, this study was designed toformulate a multimedia-based integrated learning model of Concrete Construction with entrepreneurship. It is expected that through this integrated learning model, students can create a product from the practices, such aspractical columns, floor beam, footplates, sinks and others that can be sold in the market. Through the synergy of this integrated learning and utilization multi-media, it is expected that the students have a strong entrepreneurship spirit and even can provide employment for other people. Furthermore, a valid and reliable entrepreneurial learning model will be obtained from this study to be applied as an alternative learning model for vocational institutions especially those that lead the development of independent entrepreneurs.

Development of learning models according to Joyce et al.[15]is a plan that involves learning tools that will be used for learning in class, meaning that each model directs the instructor in designing learning to help students achieve learning goals. Meanwhile, according to The law of Ministry of National Education No 103, in 2014, the learning model is a conceptual and operational learning framework that has names, features, logical sequences, settings, and culture. The characteristics of the learning model are: (1) the stages must be rational both theoretically and in a logical order, (2) focused on student learning, (3) learning activities run smoothly, and (4) there is support for the learning environment. Learning models are grouped into four, among others: (1) information development models, oriented to the ability of students to process information to improve their abilities, (2) personal models, oriented to individual development, (3) social models, emphasizing harmonious relationships between individuals with the community, and (4) behavioral system models, aiming to develop efficient systems for 
sequencing learning tasks by manipulating reinforcement[15].

While in this study the development of the multi-media based integrated learning is included in the development model of behavior system-oriented model, which in the process, it is produced an effective learning model and its supporting supplements to be implemented in the classroom. The integration process between Entrepreneurship and Concrete Construction can be performed in various ways. Ministry of National Education [16] explained that the integration process of entrepreneurship education does not need to create a new curriculum, but it is enough to integrate it into the curriculum component. The integration of entrepreneurship education inside each education unit is based on the framework presented in Figure 1.

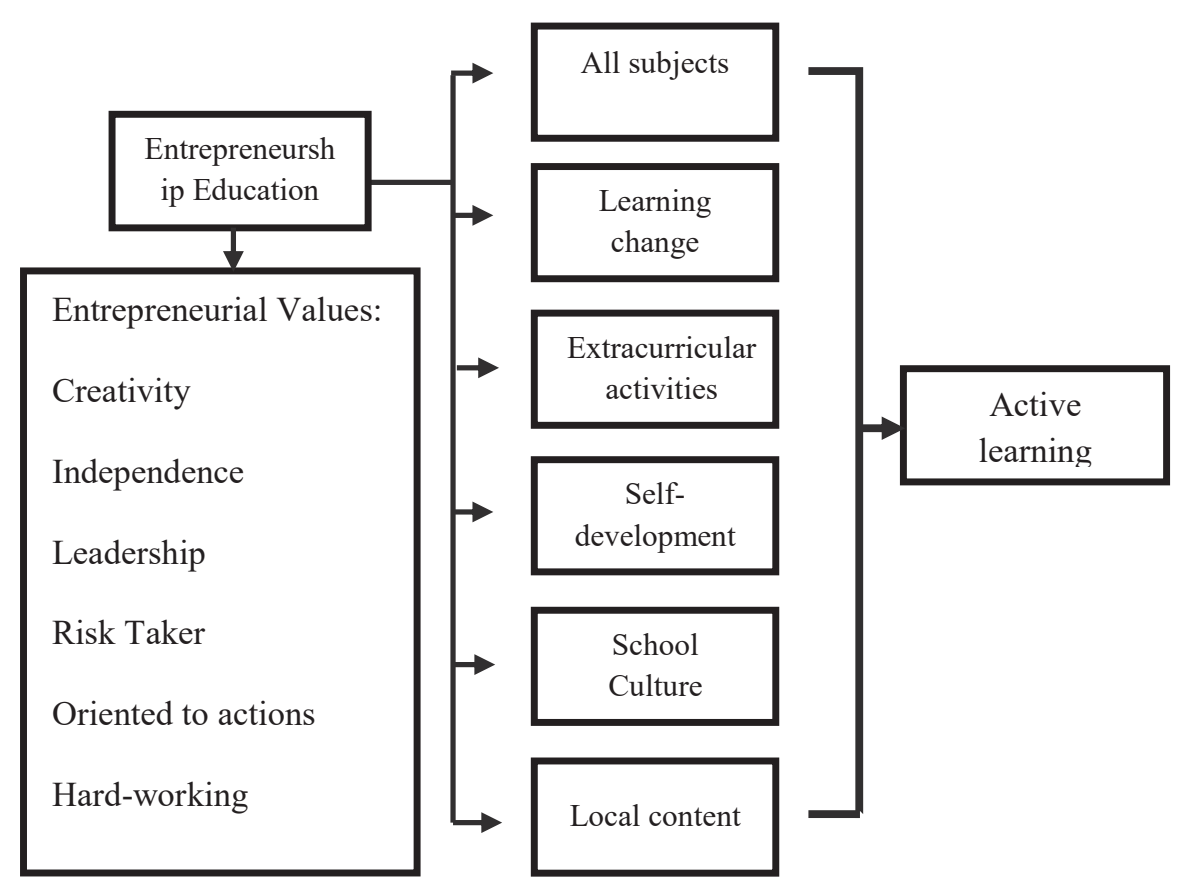

Figure 1. Framework for Integrating Entrepreneurship Education in Every Education Unit

In the learning process, entrepreneurial values can be integrated into the learning process of Concrete Construction help students obtain awareness of the importance of entrepreneurial values, to for entrepreneurial characters and to instill an entrepreneurial spirit in daily life[16]. In this integration, students do not just accept the learning and master the expected competencies, but they are directed to recognize, realize, care, feel until embedding the entrepreneurial values then brought them into daily life patterns as an entrepreneurial habit.

Many entrepreneurial values can be instilled in all subjects in the curriculum. However, not all subjects must instill entrepreneurial values with the same intensity, because if this happens it will be very burdensome for the students, instructors, institutions and related elements. Therefore, the integration of entrepreneurial values should be in subjects whose characteristics are aligned to instill entrepreneurship values. This should perform step by step by selecting several core values as a base for planting other entrepreneurial values. These new core values are only integrated into one related subject. The subject of integration only focuses on certain basic values closest to the characteristics of the subjects. The main entrepreneurship values that can be integrated according to the Ministry of National Education [16]are (1) Creativity, (2) Independence, (3) Risk-taker, (4) Leadership, (5) Oriented to actions and (6) Hard work. 
These six core values are in harmony with the characteristics of the subject of Concrete Construction.

Integration of entrepreneurial values in the subject of Concrete Construction can be done from the planning, implementation and evaluation stages of learning. The technique can be done in the materials delivery, learning models, learning methods and assessment systems. At the planning stage, the syllabus and lesson plan should be designed so that the substance and learning activities facilitate the process of integrating entrepreneurial values. The core of integrating entrepreneurial values is to facilitate the students to recognize, accept and foster entrepreneurial values in their personalities, which ultimately leads to the formation of characters by his beliefs. Thus in the deep learning process through the integration of entrepreneurial values, students are not only learning through the process of thinking and behaving but also produce a competitive product to sell by the needs of the business and the industry.

Integrated learning enables students to be involved directly. Teachers can motivate students to achieve learning goals optimally, and stimulate students to further learn the materials. Thus integrated learning emphasizes soft skills and hard skills in a unified package of a curriculum. Drake [17] statesthat the integrated curriculum is intended to create a curriculum that is in line with their learning needs. Integrated curriculum is intended to form "know", "do" and "be". "Know" is oriented to big ideas and big understanding, "Do" underlies big skills, "Be" builds attitudes, beliefs and behavior. In integrated learning, these elements are synergistically achieved simultaneously.

The universal concept of an integrated curriculum is an idea of learning in a big idea frame. This also shows the high degree of learning ideas at the level of "Know". While the essence of learning that can be generalized is the big understanding side.

This concept also means that understanding of learning can survive continuously as a result of past learning. General skills learned by students are a collection of big skills. This illustrates that teaching which forms skills students are built from a continuous learning process. Therefore "do"always related to "know", like students learn to assemble concrete reinforcement and place it in the tensile area when it will be made as a reinforced concrete plate.

In a teaching and learning process, two important interrelated elements arelearning models and learning media. The development of certain learning models will affect the type of appropriate learning mediaalthough there are still various other aspects that must beconsidered. While advances in technology require learning to usevarious instructional media. Learning media today fastly develop, where learning activities have been headed towardsthe use of multimedia technology by leaving the conventional method. This can be seen in the learning activities that emphasizecompetencies related to process skills, such as Concrete Construction, the role of instructional media is increasingly important.

The combination of texts, arts, sounds, animations,and videos deliveredthrougha computer is referred to as multimedia technology[18].If images and animation in the form of text and audio in a process learning are packaged in synergy in the form of learning media, they will give clear meaning for students. Schoeder in Prayudita [19] suggested that teachers can attract students' attention, explain difficult material to be more easily understood, and encourage pleasure in learning.

By looking at several characteristics, the learning model developed in this study is very suitable to be packed with multimedia technology. This has several advantages: (1) overcoming weaknesses in the group and individual learning, (2) learning uses more concrete approaches, (3) allows repetition oflearning with the same materials, (4) allows individual learning, (5) prevent technological backwardness, especially in information technology, (6) as a choice of practical learning 
media, (7) building learning motivation through the presentation of different media. In general, this learning model can be described in Figure 2 but this study only focused on the entrepreneurial spirit.

The learning process should have a purpose, thus the teaching materials delivered by teachers can be easily understood by students. In general, improvement to increase the degree, level, and quality as well as quantity. Improvement can also mean adding skills and abilities.Also, improvement means achievement in the process, size, nature, relationships and soon. The word improve is usually used for positive meaningsthat have the meaning of effort to make something better than before.
Efforts to achieve an improvement usually require good planning and execution. The planning and execution must be interconnected and do not deviate the intended purpose. Improvement is indicated by the change from a negative state or trait into a positive one. While the results of an improvement can be in the form of quantity and quality. Quantity is the sum of results from a process with the aim of improvement. While the quality describes the value of an object due to the process which has the goal of improvement. The results of improvement are also marked with the achievement of objectives at a certain point. Where when a business or process has arrived at that point then satisfaction and pride will arise for the expected achievement.

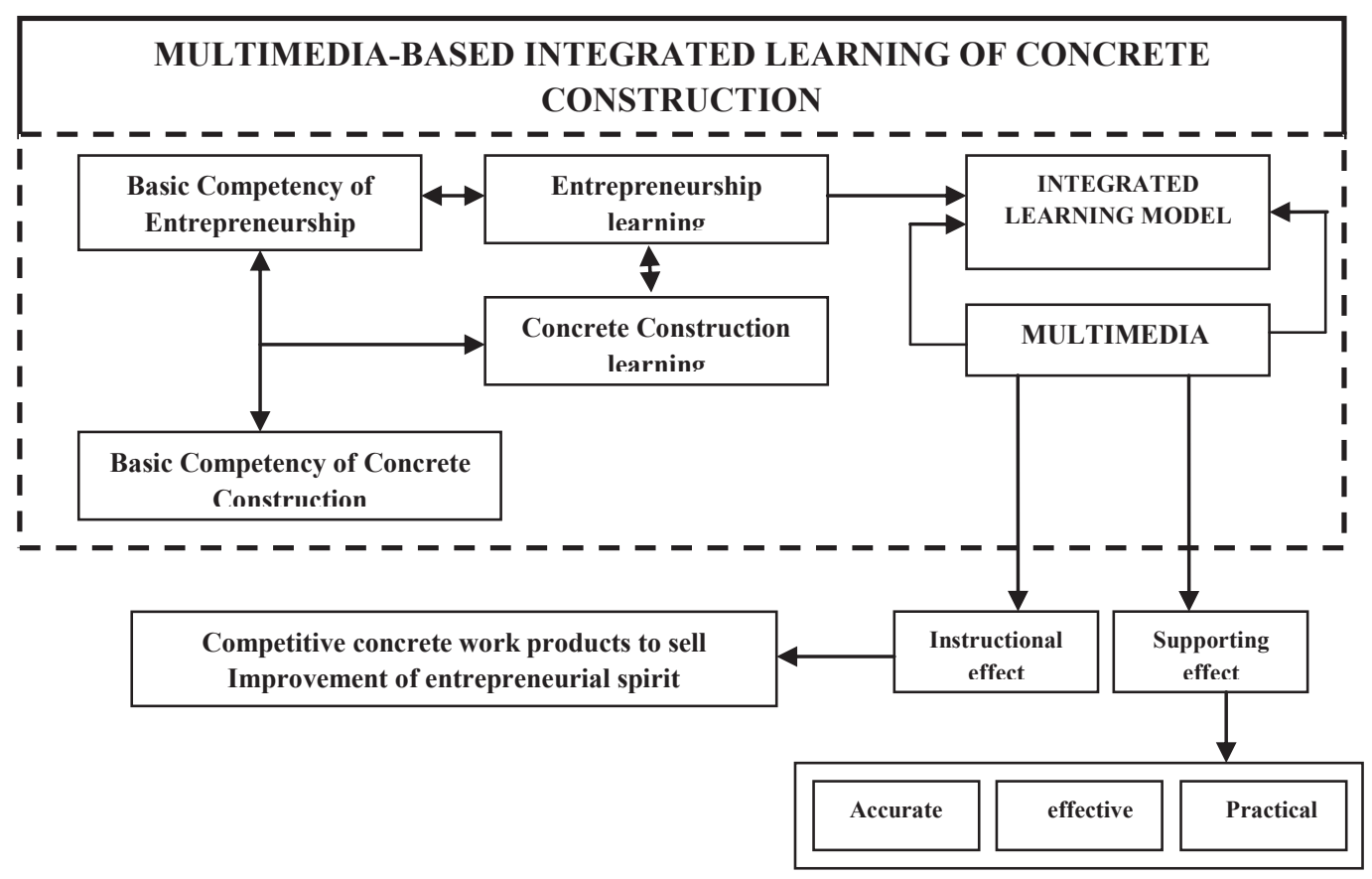

Figure 2. Multimedia-based Integrated Learning Model

The entrepreneurial spirit is a strong belief and acceptance of entrepreneurial behavior, willingness to work hard, and have relationships between members, which means there is a strong desire from members to remain in psychological bonds where they are entrepreneurial[20].

This limit can be interpreted as the will, desire and ability to undertake a certain activity and this depends on the level of maturity, past experiences, mental states and emotions of people who study. Whilematurity forms the nature and strength within oneself to react in certain ways [21]. Someone's maturities are personal traits and strengths that develop and enable people to be able to adjust to their environment and be able to solve the problems they face. The entrepreneurial spirit in the 
development of maturity is very necessary for every learning process carried out by humans. Thorndike in Amsari \& Mudjiran [22] argues that the learning process is an association between stimulus and response that follows the following laws: (1) the law of readiness, the more ready an organism is to obtain a change in behavior, the implementation of that behavior will lead to individual satisfaction so that the association tends to be strengthened, (2) the law of exercise, the more often a behavior is repeated or trained, the association is stronger, (3) the legal effect, the stimulus-response relationship tends to be strengthened if the effect is pleasing and tends to be weakened if the effect is not satisfying.

Bower \& Hilgard [23] argue that satisfaction and failure depend on one's readiness to accept or reject the response that comes. Here the entrepreneurial spirit tends to be interpreted more as a form of response of someone to accept or reject something (reinforcement) that is being studied which includes the ability to placing himself mentally and physically [24].

The student's maturity fosters mental capacity while influencing learning activities and their entrepreneurial spirit to work after he graduated. A person who has a high entrepreneurial spirit is (1) confident, confident that what he does will succeed despite facing various obstacles, he is not always haunted by a fear of failure, thus making himself optimistic for keep going forward, (2) taking the initiative, always trying to find a way out, not confined by the situation and environmental conditions, (3) having achievement motives, several targets are always designed to achieve success if it is faced with a failure condition, it will continue to be strived to improve conditions of failure, (4) have a leadership spirit, dare to be different and dare to take risks with full calculation, and (5) like challenges, need a more dynamic life to satisfy the needs of the challenges [25].

Based on these thoughts, the term improving entrepreneurial spirit in this study can be interpreted as the ability of a person (student) who has the entrepreneurial insight to be able to improve themselves. While Sudjana [26] states that learning outcomes are abilities possessed by students after participating in learning. UNESCO in Nurtanto \& Sofyan [27] argue that learning outcomes or abilities to be achieved consist of four pillars, namely: (1) learning to know, (2) learning to do something, (3) learning into something, and (4) ) learn to live together.The pillars are in line with the Education system in Indonesia, which has implemented an education system that considers students as fully human. Knowledge, skills, attitudes, and values are important both for prospective workers and graduates who have worked. In line with the goal of vocational education, hence an improvement of entrepreneurial spirit in this study is the same as increasing the ability to work. A student is called ready to be an entrepreneur if he has been had an entrepreneurial spirit that includes aspects of knowledge, skills and certain attitudes that are appropriate to their area of expertise. Considering knowledge, skills, attitudes, and values were obtained through learning, the increase in the entrepreneurial spirit in this study is also related to students' learning outcomes in the cognitive, affective and psychomotor.

\section{METHOD}

This study used a quasi-experimental research design. According to Sugiyono[28], there are two forms of quasi-experiment namely time-series design and nonequivalent control group design. The design used in this study was the nonequivalent control group, design model. Before the treatment, the experimental and control groups did a pretest to equalize the initial ability of the groups. Then after treatment, the experimental group and the control group did a posttest, to find out the condition of the groups after the treatment. Schematically the research design can be described in Table 1. 
Table 1. Research Design

\begin{tabular}{llll}
\hline Group & Pretest & Treatment & Posttest \\
\hline Experimental & $\mathrm{O} 1$ & $\mathrm{X} 1$ & $\mathrm{O} 2$ \\
Control & $\mathrm{O} 1$ & $\mathrm{X} 2$ & $\mathrm{O} 2$ \\
\hline
\end{tabular}

Explanation:

O1 : Pretest of entrepreneurial materials

XI : Treatment with the multimediabased integrated learning model combined with demonstrations:

X2 : Treatment with lectures combined with a demonstration in the control group

O2 : Posttest of entrepreneurial materials
In this study, the experimental group used a multimedia-based integrated learning model combined with demonstrations, and the control groups used the conventional methods using lectures and demonstrations. This study was conducted in the workshop of Stone Installation and ConcreteConstruction, Department of Civil Engineering and Planning Education, Faculty of Engineering, Universitas Negeri Yogyakarta. This study was conducted in 8 meetings for both groups. The research schedule is presented in Table 2 .

Table 2. Research Schedule

\begin{tabular}{|c|c|c|c|c|}
\hline \multirow[t]{2}{*}{ No } & \multirow[t]{2}{*}{ Week } & \multirow[t]{2}{*}{ Group } & \multicolumn{2}{|c|}{ Description of the learning process } \\
\hline & & & Entrepreneurship & Concrete Construction \\
\hline \multirow{2}{*}{1} & I & Experimental (X1) & Introduction and Pretest & \\
\hline & I & Control (X2) & Introduction and Pretest & \\
\hline \multirow{2}{*}{2} & II & Experimental (X1) & Creativity & Reinforcement Steel Stirrups \\
\hline & II & Control (X2) & Creativity & Reinforcement Steel Stirrups \\
\hline \multirow{2}{*}{3} & III & Experimental (X1) & Independence & Main reinforcement practical column \\
\hline & III & Control (X2) & Independence & Main reinforcement practical column \\
\hline \multirow{2}{*}{4} & IV & Experimental (X1) & Leadership & $\begin{array}{l}\text { Arranging begel and reinforcement of a } \\
\text { practical column }\end{array}$ \\
\hline & IV & Control (X2) & Leadership & $\begin{array}{l}\text { Arranging begel and reinforcement of a } \\
\text { practical column }\end{array}$ \\
\hline \multirow{2}{*}{5} & $\mathrm{~V}$ & Experimental (X1) & Risk-taker & $\begin{array}{l}\text { Main reinforcement and reinforcement } \\
\text { for concrete plates }\end{array}$ \\
\hline & $\mathrm{V}$ & Control (X2) & Risk-taker & $\begin{array}{l}\text { Main reinforcement and reinforcement } \\
\text { for concrete plates }\end{array}$ \\
\hline \multirow{2}{*}{6} & VI & Experimental (X1) & Oriented to actions & $\begin{array}{l}\text { Arranging main reinforcement and } \\
\text { reinforcement for concrete plates and } \\
\text { making the beginning }\end{array}$ \\
\hline & VI & Control (X2) & Oriented to actions & $\begin{array}{l}\text { Arranging main reinforcement and } \\
\text { reinforcement for concrete plates and } \\
\text { making begisting }\end{array}$ \\
\hline \multirow{2}{*}{7} & VII & Experimental (X1) & Hard-working & Casting a concrete plate \\
\hline & VII & Control (X2) & Hard-working & Casting a concrete plate \\
\hline \multirow{2}{*}{8} & VIII & Experimental (X1) & Post-test & \\
\hline & VIII & Control (X2) & Post-test & \\
\hline
\end{tabular}

The population consisted of students who followed the subject of Concrete Construction, in the third semester, at the Department of Civil Engineering and Planning Education, FacultyEngineering, Universitas Negeri Yogyakarta. The total population was 113 students organized into 6 classes, with the following class distribution $\mathrm{A} 1=19, \mathrm{~A} 2=21$, $\mathrm{B} 1=20, \mathrm{~B} 2=16, \mathrm{C} 1=15$ and $\mathrm{C} 2=22$ students. While the samples in this study were two classes namely the experimental and the control groups. The samples were selected randomly from 6 classes. The experimental and the control groups were also selected randomly namely A2 with 21 students and $\mathrm{C} 2$ with 22 students respectively.

There are two research variables: (1) the dependent variable, improvement of entrepreneurial spirit and (2) the independent variables divided into two categories, namely (a) learning with integrated multimedia-based learning model combined with demonstrations 
in the experimental group, (b) learning with lectures combined with demonstrations in the control group.

The operational definition of entrepreneurial spirit improvement is the improvement of learningachievement from integrated learning between entrepreneurship and concrete construction. Learning duration in onemeetingwas $4 \times 50$ minutes, divided into entrepreneurial learning for $1 \times 50$ minutes and Concrete Construction for $3 \times 50$ minutes.

The measurement of entrepreneurial spiritincluded the aspects of (1) entrepreneurial knowledge including (a) creativity, (b) independence, (c) leadership, (d) risk taker, (e)oriented to action, and (f) hard working; (2) knowledge of concrete constructionincluding: (a) how to make reinforcement bolt for practical columns, (b)how to make the main reinforcement of a practical column, (c) how to joinreinforcement bolt and the main reinforcement bar to make a series ofreinforcedpractical column, (d) how to create a series of mainbar anddistribution bar for the construction of concrete slabs, (e)How to makeformworkfor concrete slabs, and (f) concrete casting and its maintenance; (3)concrete construction skills including: (a) making reinforcement bolt for practical columns, (b) making the main reinforcement bar of a practical column, (c) joining reinforcement bolt and the main reinforcement to make a series of reinforced practical column, (d) making a series of mainbar and distribution bar for the construction of concrete slabs, (e) making formwork for concrete slabs, and (f) casting concrete and its maintenance. Thus the entrepreneurial spirit is an average learning achievement from entrepreneurial knowledge, and concrete construction knowledge and skills.

Data were collected through tests to measure entrepreneurial knowledge and knowledge of Concrete Construction. Meanwhile, to measure the skills it was used final product assessment. The instruments are presented in Tables 3, 4 and 5.

Table 3. Instrument Grid of Entrepreneurial Knowledge

\begin{tabular}{|c|c|c|}
\hline Variable & Subvariable & Indicator \\
\hline \multirow{6}{*}{$\begin{array}{l}\text { Entrepreneurial } \\
\text { spirit }\end{array}$} & \multirow{6}{*}{$\begin{array}{l}\text { Entrepreneurial } \\
\text { Knowledge }\end{array}$} & Creativity \\
\hline & & Independence \\
\hline & & Risk-taker \\
\hline & & Leadership \\
\hline & & Oriented to \\
\hline & & Hard-working \\
\hline
\end{tabular}

Table 4. Instrument Grid of Concrete Construction Knowledge

\begin{tabular}{lll}
\hline \multicolumn{1}{c}{ Variable } & \multicolumn{1}{c}{ Sub variable } & \multicolumn{1}{c}{ Indicator } \\
\hline & & Reinforcement bolt for practical columns \\
& & Main reinforcement bar of a practical \\
& & \\
& & \\
Entrepreneurial & Knowledge of Concrete & Joint of reinforcement bolt and main \\
spirit & Construction & reinforcement bar for practical column \\
& & Joint of main bar and distribution bar for \\
& concrete plates \\
& & Formwork \\
& Casting concrete \\
\hline
\end{tabular}

The validity testing of the instruments used content validity by consulting to the expert judgment, whereas for the instruments' reliability, and analysis was carried out using Cronbach alpha.To see the effect of thetreatment between the experimentaland control groups, the data were analyzed with a ttest. The analysis requirements, which include: (a) data normality test, and (2) homogeneity test variance of each data group was performed before conducting the t-test. 
Table 5. Instrument Grid of Skills of Concrete Construction

\begin{tabular}{|c|c|c|}
\hline Variable & Subvariable & Indicator \\
\hline $\begin{array}{l}\text { Entrepreneurial } \\
\text { spirit }\end{array}$ & $\begin{array}{l}\text { Knowledge of Concrete } \\
\text { Construction }\end{array}$ & $\begin{array}{l}\text { Making reinforcement bolt for practical } \\
\text { columns } \\
\text { Making the main reinforcement bar of a } \\
\text { practical column } \\
\text { Joining reinforcement bolt and the main } \\
\text { reinforcement to make a series of reinforced } \\
\text { practical column } \\
\text { Making a series of main bar and distribution } \\
\text { bar for the construction of concrete slabs } \\
\text { Making formwork for concrete slabs } \\
\text { Casting concrete and its maintenance }\end{array}$ \\
\hline
\end{tabular}

\section{RESULTS AND DISCUSSION}

The data described in this study is broadly divided into two, (a) entrepreneurial spirit pretest, and (b) entrepreneurial spirit posttest. The pretest was performed in the first meeting arranged with a combination of entrepreneurial knowledge materials and Concrete Construction materials. It consisted of 24 item items, in which 12 items each for entrepreneurship materials and Concrete Construction materials. The scoring was performed with a rating scale of 0 to 100 . The materials of Concrete Construction was not included in the pretest since both groups are assumed to have the same initial ability because in the third semester, students had followedConcrete Construction and Stone Installation Practice I and II in the first and second semesters. While the materials of the posttest consist of a combination of entrepreneurial knowledge including 30 items of multiple-choice questions, Concrete Construction knowledge including 30 items of multiple-choice questions, and practical skills with an assessment of process and results.

The three learning outcomes were calculated on average as an entrepreneurial spirit variable score.Table 6 presents the frequency distribution of the experimental group's pretest while Table 7 describes the frequency distribution of the control group's pretest.

The pretest scores of individual subjects were matched between individuals; then from the matching process, a t-test was performed. This process aims to equalize the initial ability of the research subjects. Matching Results in this study onlyallow 17 pairs between the experimental and control groupswhich can be analyzed by a t-test.

Table 6. Frequency Distribution of Experimental Group's Pretest

\begin{tabular}{cccc}
\hline No & $\begin{array}{c}\text { Class } \\
\text { Intervals }\end{array}$ & $\begin{array}{c}\text { Absolute } \\
\text { Frequency }\end{array}$ & $\begin{array}{c}\text { Absolute } \\
\text { Frequency }\end{array}$ \\
\hline 1 & 54.5 to 57.5 & 5 & $23.80 \%$ \\
2 & 57.5 to 60.5 & 4 & $19.05 \%$ \\
3 & 60.5 to 63.5 & 3 & $14.29 \%$ \\
4 & 63.5 to 66.5 & 4 & $19.05 \%$ \\
5 & 66.5 to 69.5 & 3 & $14.29 \%$ \\
6 & 69.5 to 72.5 & 2 & $9.52 \%$ \\
& Total & 21 & $100 \%$ \\
\hline
\end{tabular}

Table 7. Frequency Distribution of Control Group's Pretest

\begin{tabular}{cccc}
\hline No & $\begin{array}{c}\text { Class } \\
\text { Intervals }\end{array}$ & $\begin{array}{c}\text { Absolute } \\
\text { Frequency }\end{array}$ & $\begin{array}{c}\text { Absolute } \\
\text { Frequency }\end{array}$ \\
\hline 1 & 54.5 to 57.5 & 2 & $9.09 \%$ \\
2 & 57.5 to 60.5 & 5 & $22.73 \%$ \\
3 & 60.5 to 63.5 & 4 & $18.17 \%$ \\
4 & 63.5 to 66.5 & 5 & $22.73 \%$ \\
5 & 66.5 to 69.5 & 3 & $13.64 \%$ \\
6 & 69.5 to 72.5 & 3 & $13.64 \%$ \\
& Total & 22 & $100 \%$ \\
\hline
\end{tabular}

Test results show there are no significant differencesbetween the two groups. It indicated that the initial ability of each subject in both the experimental and control groups were same $(\mathrm{t}=1.73 ; \alpha=0.05 ; \mathrm{dk}=15 ; \mathrm{t} 0.975=$ 2.13). After the pretest data matching process, the treatment was conducted, i.e.in the second to the seventh meeting, and in the eighth 
meeting, it was carried out the posttest.Table 8 presents the frequency distribution of the experimental group's posttest and Table 9 shows the Frequency Distribution of Control Group's Posttest

Table 8. Frequency Distribution of Experimental Group's Posttest

\begin{tabular}{cccc}
\hline No & Class & Absolute & Absolute \\
\hline 1 & 79.5 to 81.5 & 2 & $11.76 \%$ \\
2 & 81.5 to 83.5 & 2 & $11.76 \%$ \\
3 & 83.5 to 85.5 & 3 & $17.66 \%$ \\
4 & 85.5 to 87.5 & 4 & $23.53 \%$ \\
5 & 87.5 to 89.5 & 4 & $23.53 \%$ \\
6 & 89.5 to 91.5 & 2 & $11.76 \%$ \\
& Total & 17 & $100 \%$ \\
\hline
\end{tabular}

Table 9. Frequency Distribution of Control Group's Posttest

\begin{tabular}{cccc}
\hline No & Class & Absolute & Absolute \\
\hline 1 & 79.5 to 81.5 & 2 & $11.76 \%$ \\
2 & 81.5 to 83.5 & 4 & $23.53 \%$ \\
3 & 83.5 to 85.5 & 5 & $29.41 \%$ \\
4 & 85.5 to 87.5 & 3 & $17.66 \%$ \\
5 & 87.5 to 89.5 & 2 & $11.76 \%$ \\
6 & 89.5 to 91.5 & 1 & $5.88 \%$ \\
& Total & 17 & $100 \%$ \\
\hline
\end{tabular}

Data analysis focused on the posttest data. The hypothesis in this study was the entrepreneurial spirit of students treated with the developed multi-media based integrated learning modelscombined with demonstrations was higher than students treated with the conventional method of lectures and demonstrations. Before the research hypothesis was tested with a t-test, related data were tested statistically as a requirement for the hypothesis testing, which includes the data normality test and the data variance homogeneity test using
SPSS version 22. The normality test used the Kolmogorov Smirnov test. Test results show that the distribution of entrepreneurial spirit data both on experimental and control groups had a normal curve with a level significance of 0.05. Similarly, for the homogeneity test of variance, both the experimental and control group's data distribution have homogeneous variance at a significance level of 0.05 .

Based on the test requirements analysis, the results met the analysis requirements, the research hypothesis test was then performed with the parametric statistical t-test. Based on the statistical test results obtained the value of $t$ $=6.99$ with $\mathrm{p}=0.00$, with the mean experimental group $(\mathrm{Xe})=86.29$ and $(\mathrm{SDe})=$ 3.09 ; the mean of the control group $(\mathrm{Xk})=$ 84.47 and $(\mathrm{Sdk})=2.60$.

From the results of the t-test; (count $=$ $3.04 ; \alpha=0.05 ; \mathrm{dk}=15 ; \mathrm{t} 0.975=2.13)$, the group average experiment (Xe) of 86.29 was higher than average of control group (Xk) of 84.47. It can be said that there were significant differences in students' entrepreneurial spirit between the experimental and the control groups. These results suggested the instructors of Concrete Construction in the Department of Civil Engineering and Planning Education, UNY that a multimedia-based integrated learning model of Concrete Construction with Entrepreneurship combined with demonstrations can be an alternative learning model to teach concrete construction or other subjects with similar characteristics. The detailed outline of the entrepreneurial spirit and learning outcomes are presented in Tables 10, 11,12 , and 13 .

Table 10. Posttest Comparison of Entrepreneurial Spirit

\begin{tabular}{cccccc}
\hline No & Group & \multicolumn{3}{c}{ Score Range } & Total \\
\hline & & $(76$ to 80$)=\mathrm{B}+$ & $(81$ to 85$)=\mathrm{A}-$ & $(86$ to 100$)=\mathrm{A}$ & \\
\hline 1 & Experiment & to & 7 & 10 & 17 \\
2 & Control & to & 11 & 6 & 17 \\
\hline
\end{tabular}

Table 11.Posttest Comparison of Entrepreneurial Spirit in the Aspect of Concrete Construction Knowledge

\begin{tabular}{cccccc}
\hline No & Group & \multicolumn{3}{c}{ Score Range } & Total \\
\hline & & $(76$ to 80$)=\mathrm{B}+$ & $(81$ to 85$)=\mathrm{A}-$ & $(86$ to 100$)=\mathrm{A}$ & \\
\hline 1 & Experiment & 2 & 5 & 10 & 17 \\
2 & Control & 1 & 11 & 5 & 17 \\
\hline
\end{tabular}


Table 12. Post test Comparison of Entrepreneurial Spirit in the Aspect of Entrepreneurial Knowledge

\begin{tabular}{cccccc}
\hline No & Group & \multicolumn{3}{c}{ Score Range } & Total \\
\hline & & $(76$ to 80$)=\mathrm{B}^{+}$ & $(81$ to 85$)=\mathrm{A}-$ & $(86$ to 100$)=\mathrm{A}$ & \\
\hline 1 & Experiment & 1 & 8 & 8 & 17 \\
2 & Control & 3 & 9 & 5 & 17 \\
\hline
\end{tabular}

Table 13.Posttest Comparison of Entrepreneurial Spirit in the Aspect of Concrete Construction Skills

\begin{tabular}{cccccc}
\hline No & Group & \multicolumn{3}{c}{ Score Range } & Total \\
\hline & & $(76$ to 80$)=\mathrm{B}+$ & $(81$ to 85$)=\mathrm{A}-$ & $(86$ to 100$)=\mathrm{A}$ & \\
\hline 1 & Experiment & 1 & 7 & 9 & 17 \\
2 & Control & 2 & 9 & 6 & 17 \\
\hline
\end{tabular}

Distribution of the score of entrepreneurial spirit for the experimental group with a score $(81$ to 85$)=$ A-: $41.18 \%$ and score (86 to 100$)=$ A: $58.82 \%$, while for the control group score $(81$ to 85$)=\mathrm{A}-: \quad 64.71 \%$ and score $(86$ to 100$)=\mathrm{A}: 35.29 \%$. The details are described in Table 11.

This study cannot be said as a pure experimental study, because some variables that influence the dependent variable cannot be controlled strictly, therefore this study is more suitable to be said as a quasi-experimental study. Control of dependent variables was mainly subject to internal validity and external validity. Internal validity is validity related to the extent of the causal relationship between the independent variable and the dependents variable in this study. Control is carried out for the aspects of (a) history, controlled through the use of two sample groups that have the same initialability, pretest and matching, (b) maturation, controlled through the use of two groups of samples at relatively the same age, used classes in the same semester, (c) testing, controlled through the use of varied test items, (d) statistical regression, controlled through the use of instruments that have been tested for reliability, (e) selection, this factor is controlled through the use of two groups of samples that have the same relative basic ability, (f) mortality, controlled through face-to-face learning that is not too long, just 8 times meetings, (g) interaction effect, controlled through the use of sample groups that have never received the same treatment, (h) instrumentation effect, controlled through the use of instruments that have been tested for validity, (i) experimental effect, controlled through the use of an intact teacher for avoiding direct interaction between researchers with both groups, (j) participant sophisticated, controlled through the use of two groups of samples that have never experienced and know the treatment patterns in the experiments in depth.

External validity is the validity associated with the problem of generalizing research results, including (a) interaction of selection and treatment, controlled through randomization of the class that will be used as a control and experimental groups, (b) interaction of setting and treatment, controlled by generalizing of populations that have the same characteristics as the sample, (c) multiple treatment interference, controlled through the guarantee that the two sample groups have never received this treatment before.

\section{CONCLUSION}

From the results of data analysis and discussion of research results, it can be concluded that the entrepreneurial spirit of students at the Department of Civil Engineering and Planning Education, Faculty of Engineering, Universitas Negeri Yogyakarta treated with a multimedia-based integrated learning model combined with demonstrations was significantly different from the entrepreneurial spirit of the students treated with conventional learning (lectures combined 
with demonstrations). This study suggested that teachers who teach Concrete Construction or other subjects with the same characteristics to implement this developed learning model as an alternative learning model for practical learning in workshops.

\section{REFERENCES}

[1] S. Suyitno, I. Widianto, and S. binti Masrul, "Development of Learning Media for the Course of Two-Stroke Gasoline Motors to Improve Students' Learning Outcomes," J. Pendidik. Teknol. dan Kejuru., vol. 24, no. 1, pp. 83-90, Apr. 2018, doi: 10.21831/JPTK.V24I1.18008.

[2] N. Luthan, Putri Lynna A Sitanggang, "Rencana Pembelajaran Semester Mata Kuliah Estimasi Biaya," Universitas Negeri Medan, 2018.

[3] Indonesian Ministry of Education and Culture, Regulation of the Minister of National Education of the Republic of Indonesia No.103 about TeachingLearning Process in Primary and Secondary Education. Indonesia, 2014.

[4] D. Ayundawati, P. Setyosari, and H. Susilo, "Influence of Strategy of Learning and Achievement Motivation of Learning Achievement Class VIII Students of State Junior High School in District Blitar ," J. Educ. Pract., vol. 7, no. 32, 2016, Accessed: Apr. 13, 2020. [Online]. Available: www.iiste.org.

[5] Munawaroh, "The Influence of Teaching Methods and Learning Environment to the Student's Learning Achievement of Craft and Entrepreneurship Subjects at Vocational High School," Int. J. Environ. Sci. Educ., vol. 12, no. 4, pp. 665-678, 2017.

[6] W. N. Nasution, "The Effects of Learning Model and Achievement Motivation on Natural Science Learning Outcomes of Students at State Islamic Elementary Schools in Medan, Indonesia," J. Educ. Train., vol. 4, no. 2, p. 131, Aug. 2017, doi: 10.5296/jet.v4i2.11144.

[7] A. Jufinda and A. Irawan, "Influence analysis of instructional models and motor skills towards student achievement on sprint," J. Educ. Learn. Stud., vol. 2, no. 1, p. 31, May 2019, doi: $10.32698 / 0482$.

[8] Universitas Negeri Yogyakarta, "Kurikulum Jurusan Pendidikan Teknik Sipil Perencanaan Fakultas Teknik UNY," Yogyakarta, 2014.

[9] Y. Munadi, Media Pembelajaran Sebuah Pendekatan Baru. Jakarta: Gaung Persada Press, 2013.

[10] Indonesian Ministry of Education and Culture, "Petunjuk Teknis Program Pendidikan Kecakapan Wirausaha (PKW)," Jakarta, 2016.

[11] A. A. G. N. Puspayoga, "Menkop UKM, Puspayoga optimis rasio kewirausahaan nasional salip Malaysia pada 2019," Tribun, Surabaya, 2019.

[12] J. Primus, "Menggenjot Jumlah Ideal Pelaku Wirausaha Indonesia. Global Entrepreneurship Monitor," Kompas, 2016.

[13] S. G. Sabbaha, "Laporan observasi SMK Negeri 2 Klaten," Yogyakarta, 2017.

[14] S. Martakim, "Laporan observasi SMK Muhammadiyah Klaten," Yogyakarta, 2017.

[15] B. Joyce, M. Weil, and E. Calhoun, Models of Teaching, 9th ed. London: Pearson Educaton. Inc., 2015.

[16] Indonesian Ministry of National Education, "Pengembangan Pendidikan Kewirausahaan," Jakarta, 2010.

[17] S. M. Drake, Creating Standards-based Integrated Curriculum. California: Corwin Press a Sage Publishing Company, 2007.

[18] Y. Arifin, M. Y. Ricky, and V. Yesmaya, Digital Multimedia. Jakarta: PT. Widia Inovasi Nusantara, 2015.

[19] R. Prayudita, Pengertian Multimedia. Bandung: Universitas Pasundan, 2018.

[20] Sukirman, "Jiwa Kewirausahaan dan Nilai Kewirausahaan Meningkatkan Kemandirian Usaha melalui Perilaku Kewirausahaan," J. Ekon. dan Bisnis, vol. 20 , no. 1, 2017.

[21] W. Soemanto, Psikologi Pendidikan (Landasan Kerja Pemimpin Pendidikan). Jakarta: Rineka Cipta, 2003.

[22] D. Amsari and M. Mudjiran, "Implikasi Teori Belajar E. Thorndike (Behavioristik) dalam Pembelajaran Matematika," J. Basiedu, vol. 2, no. 2, pp. 52-60, 2018.

[23] E. R. Hilgard and G. H. Bower, Theories of Learning, 4th ed. New Jersey: Prentice-Hall.Inc, 1975. 
[24] M. H. Olson and Hergenhahn, An Introduction to Theories of Learning, 9th ed. New York: Routledge, 2016.

[25] T. Kuat, "Penumbuhan Jiwa Kewirausahaan melalui Implementasi Edupreneurship di Sekolah Menengah Kejuruan," in Seminar Nasional Pendidikan 2017 (SNP 2017), 2017, pp. 130-143.

[26] N. Sudjana, Penelitian Hasil Proses Belajar Mengajar. Bandung: PT. Remaja Rosdakarya Offset, 2013.
[27] M. Nurtanto and H. Sofyan, "Implementasi Problem-Based Learning untuk Meningkatkan Hasil Belajar Kognitif, Psikomotor, dan Afektif Siswa di SMK," J. Pendidik. Vokasi, vol. 5, no. 3, pp. 352-364, 2015.

[28] Sugiyono, Metode Penelitian Pendidikan Pendekatan Kuantitatif, Kualitatif dan $R \& D$. Bandung: Alfabeta, 2011. 